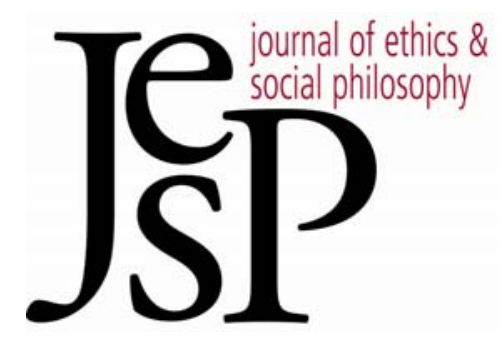

\title{
SELF-EVIDENCE AND DISAGREEMENT IN ETHICS
}

\author{
BY RYAN FANSELOW
}

Journal of Ethics \& Social Philosophy

Vol. 5, No. 3 | August 2011

URL: WWW.JESP.ORG

COPYRIGHT (C) RYAN FANSELOW 2011 


\title{
Self-Evidence and Disagreement in Ethics
}

\author{
Ryan Fanselow
}

$S^{t}$

UPPOSE JANE TELLS SARAH THAT SHE BELIEVES that active euthanasia is wrong and Sarah responds by questioning whether it is reasonable for Jane to hold this belief, or whether Jane's belief is justified. In a typical case, Jane will attempt to show that her belief about euthanasia is justified by citing a further moral belief that supports her belief about euthanasia, perhaps her belief that intentionally causing someone's death is wrong. Note that if this further belief about the wrongness of intentionally causing death is itself unjustified, it cannot justify Jane's belief about euthanasia. Thus, Sarah may ask how this further belief is justified.

Scenarios like this one show that in moral epistemology, as in general epistemology, there exists a regress problem. Most of our justified moral beliefs are inferentially justified, that is, they are justified by further beliefs. But for these further beliefs to justify any beliefs, they too must be justified. We can justify these further beliefs by citing still further beliefs but this process cannot continue ad infinitum. ${ }^{1}$ Nor is it plausible that justification travels in a circle (e.g., $P$ is justified by $Q$ which is justified by $R$ which is in turn justified by $P)$. For then we could only show that a belief is justified by assuming it in the first place. Thus, it seems that if we are to avoid moral skepticism, the regress must come to an end somewhere.

According to a traditional position in moral epistemology, which I will call moral foundationalism, the regress comes to an end with some moral beliefs. ${ }^{2}$ In order to stop the regress, these moral beliefs must meet two condi-

*I would like to thank Samuel Kerstein for his helpful written comments on multiple drafts of this paper. I also benefitted significantly from two anonymous reviewers for JESP and audiences at the Knowledge Belief, and Normativity conference at VU University in Amsterdam and the Central States Philosophical Association meeting at Northern Illinois University. At these conferences, I received helpful feedback from Robert Audi, Richard Feldman, Bruce Russell, and Walter Sinnott-Armstrong.

1 This is denied by Peter Klein in "Human Knowledge and the Infinite Regress of Reasons," Philosophical Perspectives 13 (1999): 297-325, and "What IS Wrong with Foundationalism Is That It Cannot Solve the Epistemic Regress Problem," Philosophy and Phenomenological Research 68 (2004): 166-71. I do not discuss Klein's view here since it is not open to the moral foundationalists who are the main targets of this paper.

2 Moral foundationalism is historically important because it was perhaps the dominant view in early twentieth-century moral philosophy where its defenders included Henry Sidgwick, The Methods of Ethics (London: MacMillan, 1907); G. E. Moore, Principia Ethica (Oxford: Oxford University Press, 1903); H. A. Prichard, "Does Moral Philosophy Rest on a Mistake?" Mind 21 (1912): 21-37; and W. D. Ross, The Right and the Good (Oxford: Oxford University Press, 1930). Today, the position is defended by Robert Audi in several works, including "Intuitionism, Pluralism, and the Foundations of Ethics," in Mark Timmons and Walter Sinnott-Armstrong (eds.), Moral Knowledge? New Readings in Moral Epistemology (Oxford: Oxford University Press, 1996), "Moderate Intuitionism and the Epistemology of Moral Judgment," Ethical Theory and Moral Practice 1 (1998): 15-44 and The Good in the Right (Princeton: 
tions. First, they must be justified; otherwise it is doubtful that they could inferentially justify other beliefs. Second, they must not require further beliefs in order to be justified; otherwise the regress would begin again.

Moral foundationalism is an attractive position because it promises to answer the regress problem. However, the position inherits the burden of explaining why some moral beliefs have a particular privileged epistemic position - that is, why these beliefs are justified without requiring inferential support from other beliefs. The standard answer to this question is to insist that some moral beliefs have as their content propositions that are selfevident, ${ }^{3}$ where self-evident propositions are those true propositions such that "if one adequately understands them, then by virtue of that understanding one is justified in believing them." 4

This standard version of moral foundationalism comes in both strong and weak versions. According to strong moral foundationalism, an agent $S$ is indefeasibly justified in believing any self-evident moral proposition $P$, so long as $S$ adequately understands $P$. According to weak moral foundationalism, an adequate understanding of $P$ renders $S$ defeasibly justified in believing $P$. Note that strong moral foundationalism has the odd consequence that an agent could be justified in believing some self-evident proposition $P$ even if $P$ was radically incoherent with the other things $S$ believes. For this reason, most contemporary moral foundationalists defend weak moral foundationalism, and I focus on this view in the discussion below.

Some philosophers who are not sympathetic to moral foundationalism object by denying that any moral proposition is self-evident. A well-known way of doing so is to note the deep disagreement about moral propositions among thoughtful, reflective people. As Richard Brandt puts it, "in ethics, even the doctors disagree." 5 Critics then infer from the nature of this disagreement that no moral proposition is self-evident.

Note, however, that it is not initially clear why the fact that a proposition is the subject of disagreement shows that it is not self-evident. Perhaps

Princeton University Press, 2004); as well as by Jeff McMahan in "Moral Intuition," in Hugh LaFollette (ed.), The Blackwell Guide to Ethical Theory (Oxford: Blackwell, 2000), pp. 92-110; Brad Hooker in "Intuitions and Moral Theorizing," in Philip Stratton-Lake (ed.), Ethical Intuitionism: Re-evaluations (Oxford: Oxford University Press, 2002), pp. 167-83; Philip StrattonLake in "Introduction," in David Ross, The Right and the Good (Oxford: Oxford University Press, 2002), and "Introduction" in Stratton-Lake, Ethical Intuitionism; Russ Shafer-Landau in Moral Realism: A Defense (Oxford: Oxford University Press, 2004); and Michael Huemer in Ethical Intuitionism (New York: Palgrave, 2005).

3 This is the route taken by all of the authors mentioned in the previous footnote with the exception of Huemer. Huemer's view is that we are prima facie justified in believing the propositional content of our moral intuitions. While I do not discuss Huemer's view directly below, I believe that what I claim about traditional versions of moral foundationalism applies mutatis mutandis to Huemer's view.

4 Robert Audi, Epistemology: A Contemporary Introduction, 2nd edition (London: Routledge, 1998), p. 94, emphasis in original.

${ }^{5}$ R. B. Brandt, Ethical Theory (Englewood Cliffs, NJ: Prentice-Hall, 1959), p. 200. 
these philosophers think that a self-evident proposition must be obvious, and note that reflective, thoughtful people would not disagree about something that is obvious. However, one should not be so quick to claim that a selfevident proposition must be obvious. Certain logical and mathematical propositions are candidates for being self-evident, but in some cases it requires years of training to be able to grasp these propositions. In ethics, where one's judgment is frequently distorted by self-interest, among other things, it seems especially doubtful that all self-evident propositions will be obvious. Thus, this common argument from disagreement fails.

Nonetheless, I am going to argue that the nature of moral disagreement does pose serious difficulties for moral foundationalism. This argument is more restricted than the simple argument above because it focuses solely on cases of disagreement between epistemic peers (those who are roughly equivalent to us in terms of cognitive abilities), motivation to arrive at the truth and available evidence. The argument will draw on some recent work in epistemology about the nature of our epistemic obligations in cases of peer disagreement. I begin in section 1 by defending a weak principle about what these obligations are. In section 2 , I discuss the nature and scope of moral disagreement. In section 3, I argue that the weak principle defended in section 1 and the facts about disagreement described in section 2 rule out the possibility that moral beliefs can serve as regress stoppers. Thus, the main upshot of this paper is negative. Moral foundationalism is faced with a serious objection. Nonetheless, in section 4, I argue that a coherentist position in moral epistemology can avoid these difficulties. Thus, the thesis of this paper should not be construed as a skeptical one. In the final section of this paper, I argue that this thesis has methodological implications. It rules out a position advocated by Peter Singer in his early work, according to which ethical inquiry must begin with "fundamental ethical axioms."' I suggest instead that the argument of this paper indirectly supports the method of reflective equilibrium.

\section{A Weak Principle Regarding Peer Disagreement}

As I mentioned above, there has been much recent work in epistemology about the nature of our epistemic obligations when we find that our epistemic peers disagree with us. Consider the following example:

Suppose that five of us go out to dinner. It's time to pay the check, so the question we're interested in is how much we each owe. We can all see the bill total clearly, we all agree to give a $20 \%$ tip and we further agree to split the whole cost evenly, not worrying over who asked for imported water, or skipped desert, or drank more of the wine. I do the math in my head and become highly confident that our shares are $\$ 43$

6 Peter Singer, "Sidgwick and Reflective Equilibrium," The Monist 58 (1975): 490-577. Reprinted in Helga Kuhse (ed.), Unsanctifying Human Life (Oxford: Blackwell, 2002), pp. 27-50, 48. All page references refer to the reprint. 
each. Meanwhile, my friend does the math in her head and becomes highly confident that our shares are $\$ 45$ each. How should I react, upon learning of her belief? ${ }^{7}$

Let us suppose that I know that my friend is genuinely my epistemic peer. We might, "suppose that my friend and I have a long history of eating out together and dividing the check in our heads, and that we've been equally successful in our arithmetic efforts: the vast majority of times, we agree; but when we disagree, she's right as often as I am."'

Perhaps I was justified in believing that we owe $\$ 43$ each before I learned of my friend's disagreement. However, it seems to most people who consider this case that after I become aware of my friend's disagreement, I should suspend judgment about whether or not we owe $\$ 43$ each. If the proper attitude towards the proposition "we owe $\$ 43$ each" is suspension of judgment, then it follows that I am not justified in believing that we owe $\$ 43$ each. In this case, at least, it seems that the mere fact that I am aware of disagreement regarding the proposition "we owe $\$ 43$ each," changes the epistemic status of the proposition.

Of course, epistemologists disagree about what exactly we should do in the face of peer disagreement. Richard Feldman argues that, in cases where there is widespread peer disagreement, "suspension of judgment is the proper attitude. It follows that in such cases we lack reasonable belief and so, on standard conceptions, knowledge." In contrast, Thomas Kelly writes, "disagreement does not provide a good reason for skepticism or to change one's view."10

In what follows, I defend the following weak principle:

$D$ : If an agent $S$ is aware of peer disagreement regarding some proposition $P$, then in order for $S$ to be justified in believing $P, S$ must have a further belief (a belief other than $P$ itself) that serves as a reason to believe $P$.

$D$ is a weak principle because it only claims that awareness of disagreement defeats the justification of a belief $B$ in certain cases, namely, cases in which one does not have a further belief (a belief other than $B$ ) that serves as a reason for the belief about which there is disagreement. Since most of our beliefs are supported by further beliefs, we can, at least most of the time, agree with Kelly that disagreement does not give us a reason to change our view or become skeptics.

\footnotetext{
7 Taken from David Christensen, "Epistemology of Disagreement: The Good News," Philosophical Review 116 (2007): 187-217, 193.

8 Ibid.

9 Richard Feldman, "Epistemological Puzzles about Disagreement," in Stephen Hetherington (ed.), Epistemology Futures (Oxford: Oxford University Press, 2006), pp. 216-36, 217.

10 Thomas Kelly, "The Epistemic Significance of Disagreement," in Tamar Gendler and John Hawthorne (eds.), Oxford Studies in Epistemology, Vol. 1 (Oxford: Oxford University Press, 2006), pp. 167-96, 170.
} 
I will argue for $D$ by claiming that disagreement can change the epistemic status of a proposition, such that, even if there was no need to have a further belief in order to be justified in believing $P$ before one learned of peer disagreement, there is after one learns of such disagreement. The idea that disagreement can change the epistemic status of a proposition goes back to an oft-quoted passage from Henry Sidgwick:

If I find any of my judgments, intuitive or inferential, in direct conflict with a judgment of some other mind, there must be error somewhere: and if I have no more reason to suspect error in the other mind than in my own, reflective comparison between the two judgments necessarily reduces me temporarily to a state of neutrality. ${ }^{11}$

This idea persists. ${ }^{12}$ Consider the following passage from Russ ShaferLandau:

It is true that awareness of disagreement regarding one's moral endorsements may serve as a defeater. It will do so if one has nothing to say on behalf of one's moral views, after receiving or conceiving of a challenge from a dissenter whose conflicting views are themselves coherent, compatible with the non-moral evidence, etc. Crucially, one is in a different epistemic position before and after confronting such disagreement. Prior to this sort of confrontation, one may be justified in one's belief simply because of having understood a self-evident proposition. But after the challenge is issued, one is required to defend oneself. ${ }^{13}$

The crucial idea in Shafer-Landau's passage is that awareness of moral disagreement serves as a defeater for the moral beliefs about which there is disagreement. A defeater for a belief $B$ is a further belief that undermines or overrides an agent's justification for believing B.14 In the above passage, Shafer-Landau is noting that a further belief, a belief that there is disagreement regarding one's moral endorsements, can undermine or override one's justification for holding one's moral views. While one may have been justified in holding a particular moral belief without having further beliefs that serve as reasons for that belief, after encountering peer disagreement, one requires a further reason in order to be justified in holding one's belief.

We might get clearer on Shafer-Landau's claim by considering a case. Suppose I am eating lunch with my friends Judith and Shelly, when Judith tells us the following story:

11 Sidgwick, The Methods of Ethics, p. 342.

12 In addition to the passage from Shafer-Landau quoted below, see Walter SinnottArmstrong, "Moral Relativity and Intuitionism," Philosophical Topics 12 (2002): 305-28; and Sarah McGrath, "Moral Disagreement and Moral Expertise," in Russ Shafer-Landau (ed.), Oxford Studies in Metaethics, Vol. 3 (Oxford: Oxford University Press, 2008), pp. 87-108.

13 Shafer-Landau, Moral Realism, p. 265.

14 This definition is intended to be stipulative but I believe that it accords well with ShaferLandau's usage. See his Moral Realism, p. 289. For a different definition, see John Pollock, Contemporary Theories of Knowledge (Savage, MD: Rowman \& Littlefield, 1986), p. 38. 
George is on a footbridge over the trolley tracks. He knows trolleys, and can see that the one approaching the bridge is out of control. On the track back of the bridge there are five people; the banks are so steep that they will not be able to get off the track in time. George knows that the only way to stop an out-of-control trolley is to drop a very heavy weight into its path. But the only available, sufficiently heavy weight is a fat man, also watching the trolley from the footbridge. George can shove the fat man onto the track in the path of the trolley, killing the fat man; or he can refrain from doing this, letting the five die. ${ }^{15}$

Upon hearing this story, I immediately judge that it would be wrong to push the fat man off the bridge. I form the belief that this action is wrong and perhaps this belief is justified. However, suppose Shelly has the opposite reaction; he judges that it would be morally permissible to push the fat man off the bridge.

There are many things that could explain why my friend had a different reaction to the case than I did. Perhaps my friend misunderstood the case, subscribes to a false moral theory or reasoned poorly about the case. However, as Sidgwick notes, if we are truly epistemic peers, it is just as likely that I made an error as it is that my friend made an error.

If we believe that my friend's disagreement in the restaurant case served as a defeater for my belief that we owe $\$ 43$ each, then we should accept that Shelly's disagreement in this case serves as a defeater for my judgment that it is morally impermissible to push the fat man off the bridge. Of course, this does not mean that I cannot become justified once again in believing that it was impermissible to push the fat man off the bridge. I could learn of the doctrine of double effect and note that this doctrine would forbid pushing the fat man. Perhaps inferring my judgment about pushing the fat man from the doctrine of double effect could render my judgment justified. However, this requires a further belief in order to render my judgment about the fatman case justified.

So far, our discussion of moral disagreement has been restricted to cases where I make an immediate judgment (i.e., cases where my belief is not based on a further belief that serves as a reason for my belief). However, suppose my belief is based on further beliefs that serve as reasons for my belief. Does my awareness of peer disagreement still function as a defeater?

We need not take a stand on this issue here because $D$ only requires that my awareness of peer disagreement function as a defeater when I have no further beliefs that serve as reasons for my belief. $D$ leaves open what, if anything, is required of me when I encounter peer disagreement about a belief for which I have further reasons.

15 Judith Jarvis Thomson, Rights, Restitution, and Risk (Cambridge, MA: Harvard University Press, 1986), p. 82. 


\section{Moral Disagreement}

I have been arguing that awareness of peer disagreement is a defeater for a moral belief and that to overcome this defeater requires at least a further belief that serves as a reason for the moral belief in question. However, this only raises a general worry about moral foundationalism if it turns out that there really is peer disagreement about the beliefs that moral foundationalists claim are self-evident. In this section, I argue that this is indeed the case.

Consider Sidgwick's view that the following principles are self-evident:

S1) "The good of any individual is of no more importance, from the point of view (if I may say so) of the Universe, than the good of any other."

S2) "As a rational being, I am bound to aim at good generally - so far as it is attainable by my efforts - not merely a particular part of it." 16

We do not have to search very far to find thinkers (presumably some of whom are Sidgwick's epistemic peers) who disagree with these principles. After all, deontologists deny that one ought to aim at good generally. They believe that there are cases where maximizing the good is morally impermissible.

G. E. Moore claims that it is self-evident that pleasure, beauty and aesthetic appreciation are intrinsically good. Again, it is not difficult to find those who doubt the intrinsic goodness of these properties. A hedonist will, of course, deny that beauty and aesthetic appreciation are intrinsically good.

W. D. Ross and Robert Audi claim that it is self-evident that we have certain prima facie duties (e.g., duties of honesty, beneficence, etc.). That we have these prima facie duties is less controversial than Sidgwick's principles or Moore's claims about which properties are intrinsically good, but it is still controversial. To assess how much peer disagreement there is about Audi's and Ross's claim, we must keep in mind that to say that we have a prima facie duty not to lie is not merely to imply that we often or usually have a duty not to lie. To claim that we have a prima facie duty not to lie is to claim that we have an all-things-considered duty not to lie unless lying is required by another duty. ${ }^{17}$

This latter claim is controversial. For example, it is denied by particularists such as Jonathan Dancy.18 Many utilitarians are also committed to its denial. To see this, imagine a case where telling a lie is not required by any duty and produces exactly as much overall utility as not lying. In such a case, the claim that we have a prima facie duty not to lie entails that we have an allthings-considered duty not to lie, since, by hypothesis, lying is not required by any other duties. However, the act-utilitarian will hold that we have no duty not to lie since, by hypothesis, lying produces exactly as much utility as

${ }_{16}$ Sidgwick, Method of Ethics, p. 382.

${ }^{17}$ This is Ross's understanding of prima facie duty. See Ross, The Right and the Good, p. 19.

18 Jonathan Dancy, Moral Reasons (Oxford: Blackwell, 1993), ch. 6. 
not lying. Note that, since the claim that we have a prima facie duty not to lie entails that, in this case, we have an all-things-considered duty not to lie, utilitarians who hold that we do not have an all-things-considered duty not to lie are committed to denying that we have a prima facie duty not to lie as well.

A better strategy for avoiding disagreement, pursued by Shafer-Landau, is to identify some very particular common-sense moral judgments, such as, "it is wrong to take pleasure in another's pain, to taunt and threaten the vulnerable, to prosecute and punish those known to be innocent, and to sell another's secrets solely for personal gain" and to hold that these judgments are self-evident. ${ }^{19}$ One will not find many mainstream moral theorists who will reject these claims. Still, there is at least one group of persons who would deny such claims: moral nihilists such as J. L. Mackie hold that no first-order moral propositions are true. ${ }^{20}$ Indeed, their disagreement is especially important, for it means that there is a potential defeater for all of our moral beliefs. ${ }^{21}$

I have argued that there is, in fact, disagreement about the propositions that moral foundationalists claim are self-evident. There are two lines of response open to moral foundationalists to this argument. First, the moral foundationalist may deny that the cases I discussed above constitute disagreement or she may deny that they constitute peer disagreement. I take each

${ }^{19}$ Shafer-Landau, Moral Realism, p. 248.

${ }^{20}$ J. L. Mackie, Ethics: Inventing Right and Wrong (New York: Penguin, 1977). I use Mackie as my chief example here because he is the most well-known nihilist about morality among contemporary analytic philosophers - but his work does raise a special problem. He takes ordinary moral statements such as "lying is wrong" to entail a commitment to categorical imperatives (pp. 27-30) and objective values understood as "entities or qualities or relations of a very strange sort, utterly different from anything in the universe" (p. 38). Perhaps Mackie only disagrees with statements such as "lying is wrong" when they carry these sorts of commitments with them. If someone means something more minimal when they assert "lying is wrong," then perhaps Mackie does not disagree with them at all. A moral foundationalist might attempt to disregard Mackie's apparent disagreement on the grounds that there is actually no disagreement at all.

There is some promise in this strategy but it is very limited in application. First, it is not open to those with metaethical views that attempt to preserve the features of moral discourse that Mackie finds objectionable. Second, it is of no help to the Rossian or Sidgwickian foundationalist because nihilists are hardly the only peers who reject the principles that they claim are self-evident. Third, while this may help a Shafer-Landau-style foundationalist dismiss Mackie's disagreement, Mackie is far from the only nihilist about morality and the Shafer-Landau-style foundationalist will have to use a different strategy to deal with those nihilists who do not accept Mackie's view of the commitments of moral judgments. For examples see Michael Ruse, Taking Darwin Seriously (Amherst, NY: Prometheus, 1998); Richard Joyce, The Myth of Morality (Cambridge: Cambridge University Press, 2001); John P. Burgess, "Against Ethics," Ethical Theory and Moral Practice 10 (2007): 427-39; Don Loeb, "Moral Incoherentism: How to Pull a Metaphysical Rabbit out of a Semantic Hat," in Walter SinnottArmstrong (ed.), Moral Psychology Volume 1 (Cambridge, MA: MIT Press, 2008); and Bart Streumer, "Can we Believe the Error Theory?" Journal of Philosophy (forthcoming).

${ }^{21}$ This does not apply to certain conditionals. For example, no sensible person denies that if killing is always wrong, then killing one's brother is wrong. However, no moral foundationalist holds that it is only these sorts of conditionals that are self-evident. 
of these possible responses in turn.

A moral foundationalist may concede that while it appears that there is peer disagreement about the propositions that they claim are self-evident, the appearances are misleading. In many cases the sentence one person utters seems to contradict the sentence uttered by another person. However, it does not follow that the proposition one person intends to assert contradicts the proposition the other person intends to assert. This is because the relationship between the sentences we utter and the propositions we intend to assert is complicated. Many times it appears that two sentences are contradictory but only because terms are being used imprecisely. For example, suppose I believe that there is no omniscient, omnipotent and perfectly moral being who created the universe. I come across a friend who utters the sentence, "God exists," and I utter in reply, "God does not exist." In this case, the sentences we utter make it appear that we disagree. However, suppose my friend believes that God is love and only means to be asserting that love exists. In this case we may not actually disagree, since the proposition my friend intends to assert is, "love exists," and that proposition is consistent with my atheism.

The sentences we utter are indeed imperfect guides to the propositions that we intend to assert. However, this does not show that there is less disagreement than there appears to be. I may assent to the sentence you utter only because I am mistaken about which proposition you intend to assert. Perhaps if I really knew what proposition you were trying to assert, I would dissent rather than assent to your statement. If this happens often, there may actually be more disagreement than there appears to be. Thus, the fact that the sentences we utter are imperfect guides to the propositions that we intend to assert does not show that there is less moral disagreement than there appears to be.

The second response open to the moral foundationalist is to concede that there is disagreement about the propositions she holds to be self-evident but deny that this disagreement is between epistemic peers. If those who reject candidate self-evident propositions are our epistemic inferiors, their disagreement is not relevant to our principle $D$.

The claim that those who reject candidate self-evident propositions are our epistemic peers is an empirical claim that no purely a priori argument could establish. I concede that what I say here is somewhat speculative but I believe it to be at least initially plausible. Above, I defined our epistemic peers as those who are roughly equivalent to us in terms of cognitive abilities, motivation to arrive at the truth and available evidence. It seems to me that the authors mentioned above (Dancy, Mackie, etc.) fit this description. As accomplished moral philosophers, it is likely that these persons are well informed about the relevant issues, intelligent, creative, etc. I concede that this consideration is not definitive but I also think that moral foundationalists will not want to rest their objections to my argument on this point. Moral foundationalism would be an unstable position if its plausibility depended on the 
empirical claim that its detractors were cognitively inferior.

There is an important objection to the reasoning just presented that must be considered. One who presses this objection may concede that the account of epistemic peer-hood that I have given, defined in terms of available evidence, cognitive ability and motivation to arrive at the truth, is perfectly adequate for ordinary descriptive matters. However, in moral matters, the objector claims, something else is required, which I will call a moral sensibility.22 Moral sensibilities are those capacities other than good reasoning that are required for sound moral judgment. They may include such things as emotional maturity, the ability to perceive certain facts as morally salient or even a quasi-perceptual capacity. ${ }^{23}$

I think that reflection on our moral experience compels us to accept the point that an account of epistemic peer-hood in moral matters must include moral sensibilities, though I want to remain agnostic about how exactly these sensibilities should be understood. Think of a person who is intelligent and well informed but persists in making demeaning comments about women. Such a person may have access to all the same evidence that we do and be roughly cognitively equivalent to us but such a person lacks moral sensibilities and should not be counted as our epistemic peer on moral issues. We would be permitted, I think, to dismiss their disagreement with us about what constitutes an appropriate attitude toward women on these grounds.

Nonetheless, this point does not affect the main argument. The disagreement about candidate self-evident propositions discussed above does not seem to be motivated by a lack of moral sensibilities. When Dancy denies that we have a prima facie duty to be honest, it is not because his lack of moral sensibilities precludes him from understanding the wrongness of dishonesty but because he has theoretical worries about the notion of a prima facie duty. Specifically, he worries that proposed definitions of prima facie duty are incoherent, circular or uninformative and that a theory of prima facie duties cannot give a plausible account of some of the phenomena it is supposed to explain, especially how competing reasons are related to one's overall decision. ${ }^{24}$ While in some cases theoretical worries can be motivated by a lack of moral sensibilities that does not seem to be a plausible account of this instance of disagreement. The general lesson is that while we may sometimes dismiss moral disagreement on the grounds that the agent who disagrees with us

22 Moral sensibilities might be construed as themselves being cognitive abilities. In this case they would have been, at least tacitly, included in the earlier account of epistemic peer-hood. In any case, it will be worthwhile to discuss them explicitly here.

${ }^{23}$ Lawrence Blum discusses the importance of what I am calling "moral sensibilities" in his "Moral Perception and Particularity," Ethics 101 (1991): 701-25. Barbara Herman and Allen Wood have emphasized the importance of these capacities within a Kantian framework. See Barbara Herman, “The Practice of Moral Judgment," Journal of Pbilosophy 82 (1985): 414-36 and Allen Wood, Kant's Moral Theory (Cambridge: Cambridge University Press, 1996), pp. $150-55$.

${ }^{24}$ Dancy, Moral Reasons, pp. 96-100. 
lacks moral sensibilities, this will not help the moral foundationalist dismiss the sort of disagreement discussed above.

I take it, then, that there is strong reason to think that there is peer disagreement about the propositions that moral foundationalists believe are selfevident. If such disagreement functions as a defeater in the way that I have suggested, then it follows that we (those of us aware of this disagreement) must have a further reason for our moral beliefs in order for them to be justified.

\section{Implications for Moral Foundationalism}

I now return to moral foundationalism. In this section I argue that the considerations argued for in sections 1 and 2 undermine moral foundationalism. Recall our earlier distinction between strong and weak moral foundationalism. Because the strong version implies that there are some moral propositions for which our justification could not be defeated, it is in direct conflict with the argument from sections 1 and 2. If what we have said so far is correct, there is a defeater for candidate self-evident propositions and thus strong moral foundationalism is false.

However, as I noted earlier, contemporary moral foundationalists defend weak moral foundationalism, according to which foundational moral beliefs are only defeasibly justified. On this view, understanding a self-evident proposition renders us prima facie justified in believing the proposition. This prima facie justification could be defeated if, for example, this proposition fails to cohere with our other beliefs. This claim is compatible with the thesis of sections 1 and 2 because it allows that there could be a defeater for foundational moral beliefs. Nonetheless, in what follows I argue that even if the moral foundationalist concedes that self-evident moral propositions are only prima facie justified, the argument of sections 1 and 2 rules out the possibility that moral beliefs can serve as regress stoppers.

The first thing to notice is that while one can be prima facie justified in believing a moral proposition non-inferentially, one cannot be all-thingsconsidered justified in believing a moral proposition unless they have a further belief that serves as a reason to believe it. This is because, as argued in previous sections, our awareness of peer disagreement about morality serves as a defeater for our moral beliefs unless we have a further reason for them.

Notice also that these further beliefs that serve as reasons to believe foundational moral beliefs must themselves be justified. This is because an unjustified belief cannot override or undermine a defeater. Thus, even foundational moral beliefs must ultimately be supported by further justified beliefs.

This fact shows that no moral belief can stop the regress. For a belief to stop the regress that belief must have all-things-considered justification without requiring inferential support from a further proposition. Defeated prima facie justification cannot stop the regress. However, we have seen that for 
foundational moral beliefs to have all-things-considered justification they must be supported by further beliefs and that these further beliefs must themselves be justified beliefs. We can then sensibly ask, what makes these further beliefs justified? The regress begins again.

It is worth spelling out explicitly what, if the argument so far is sound, the moral foundationalist would have to give up. The argument does not show that there are no self-evident moral propositions, so long as selfevidence is understood as conferring only defeasible justification on an agent's beliefs. ${ }^{25}$ What the argument does show is that our prima facie justification for believing self-evident moral propositions, if there are any, is defeated by our awareness of peer disagreement about these propositions. Thus, in practice, self-evident moral propositions will function much like non-selfevident moral propositions, in that they require evidential or inferential support from other beliefs in order to be justified.

This point is worth dwelling on because it is one that moral foundationalists have traditionally denied. For instance, G. E. Moore holds that the claims about goodness discussed above are self-evident, and he defines a selfevident proposition as one that is "evident or true by itself alone; that it is not an inference from some proposition other than itself." ${ }_{26}$ W. D. Ross holds that his claims about prima facie rightness are "self-evident; without any need of proof, or of evidence beyond itself." ${ }^{27}$ And Robert Audi claims that his list of prima facie duties is self-evident where "a self-evident proposition is knowable without our relying on any inferential ground for it." 28 If the argument just presented is correct, however, one cannot be justified in believing a moral proposition unless one has a further belief that serves as a reason to believe the proposition.

25 Thus, this argument is distinct from the standard objection, mentioned earlier, that holds that no moral propositions can be self-evident because persons disagree about the truth of allegedly self-evident moral propositions. The standard objection has been widely discussed by moral foundationalists (see e.g., Stratton-Lake, "Introduction" in Ethical Intuitionism and Audi, The Good in the Right, pp. 60-68). The argument here is less often discussed. It does not claim that the fact of moral disagreement shows that there are no self-evident moral propositions. Instead, this argument claims that even if there are self-evident moral propositions, the prima facie justification of these propositions is defeated. This sort of argument has received little attention from moral foundationalists. An exception is Shafer-Landau, Moral Realism, pp. 252-65, who distinguishes between these two arguments and discusses versions of both of them. However, Shafer-Landau does not discuss the fact that once the moral foundationalist concedes that further beliefs are required in order for a moral belief to be justified, the regress begins again.

${ }^{26}$ Moore, Principia Ethica, p. 143, emphasis in original.

27 Ross, The Right and the Good, p. 29.

28 Audi, The Good in the Right, p. 51, emphasis in original. 


\section{Avoiding Moral Skepticism: The Coherentist Response to the Re- gress Argument}

If the argument so far is correct, moral foundationalism as defined in the first section is false. Moral foundationalism is the view that the regress comes to an end with some moral belief(s) but in fact no moral belief is capable of stopping the regress. In this section I want to argue that the fact that no moral belief can stop the regress does not entail skepticism, so long as coherentism in moral epistemology remains a viable option. ${ }^{29}$ This is because, if coherentism is true, then no regress stoppers are required for our beliefs to be justified. While this claim is not novel, it is worth discussing here in order to emphasize that the argument of this paper need not be understood as a skeptical argument. ${ }^{30}$

In order to show this, it will be worthwhile to reexamine the regress argument that we began with. We begin by observing that most of our beliefs are justified because they bear some inferential or evidential relationship to further beliefs. We then note that in order for these further beliefs to justify other beliefs, they must be justified themselves. This gives rise to a regress and there seem to be three possibilities:

1) The regress continues ad infinitum.

2) The regress loops around in a circle (e.g., $P$ is justified by $Q$ which is justified by $R$ which is justified by $P$ ).

3) The regress is brought to an end.

The regress argument then proceeds by elimination. The idea of an infinite series of beliefs that does not circle back on itself is implausible, ruling out 1). 2) seems to involve vicious circularity. We can only show that $P$ is justified by assuming it in the first place. Thus, we are left with 3). Earlier, however, I argued that 3) is not plausible in the moral case. Thus, one might worry that if we reject 1)-3) we are committed to moral skepticism.

The regress argument relies on a conception of justification that is essentially linear. A comparison may be useful here. According to this conception, the structure of justification is, in some respects, like that of a building.

${ }^{29}$ Since the main aim of this paper is to raise a worry about moral foundationalism, I do not formulate and defend a specific version of coherentism in ethics here. Instead, I note some general features shared by all versions of coherentism in ethics and argue that these features allow coherentism to avoid skepticism even if it turns out that no moral belief can stop the regress. For defenses of specific versions of coherentism in ethics, see David Brink, Moral Realism and the Foundations of Ethics (Cambridge: Cambridge University Press), ch. 5 and Geoffrey Sayre-McCord, "Coherentist Epistemology and Moral Theory," in Sinnott-Armstrong and Timmons, Moral Knowledge?, pp. 137-89.

30 It has been made, for instance, by Laurence BonJour, The Structure of Empirical Knowledge (Cambridge, MA: Harvard University Press, 1985), pp. 87-93. My discussion here is indebted to BonJour's. It is worth noting, however, that BonJour no longer defends the coherentist position described here. See Laurence BonJour \& Ernest Sosa, Epistemology: Internalism vs. Externalism, Foundations vs. Virtues (Oxford: Blackwell, 2003). 
A building rests on a foundation, which supports the first floor, which in turn supports the second floor and so on. Each floor requires the previous floor for its structural support. ${ }^{31}$ Therefore, if one were to remove the foundation, the whole building would collapse. Suppose $S$ is a foundational belief and that it justifies $T$, which in turn justifies $U$, and so on. On the linear conception of justification, a justified $S$ is required for T's justification. If $S$ turns out to be unjustified, the whole chain of beliefs is unjustified.

One way of resisting the regress argument is to deny the linear picture of justification on which it rests. Instead of looking at a building as the appropriate model for the structure of justification, we should look to a spider's web. A particular thread derives support from nearby threads while the nearby threads derive support from each other and that particular thread. According to the coherentist nonlinear picture of justification, a belief $S$ could be justified because of its inferential relationship to $T, U$ and other propositions, while $T$ is justified because of its inferential relationship to $S, U$ and other propositions.

In our earlier discussion of the regress argument we rejected option 2), the view that a belief $B$ could be justified by a further belief $C$ that is in turn justified (eventually) by $B$, because that seemed to involve vicious circularity. It should be clear that the worry about circularity arises only if we assume a linear picture of justification. If $B$ requires $C$ for its justification and $C$ requires $D$ for its justification while $D$ requires $B$ for its justification, then we can only show that $B$ is justified by assuming it in the first place. But if justification is not linear in this way, then we are not left with this result. B can be justified by its relationship to $C, D$ and the other propositions the agent believes, while $C$ is justified by its relationship to $B, D$ and the other propositions the agent believes.

There are two things to note about this picture for our purposes. First, on the coherentist picture sketched above, every justified belief is supported by further beliefs. Therefore, every justified belief meets the condition that our weak principle holds is required for a belief to be justified in cases of disagreement. ${ }^{32}$ Second, no regress stoppers are required for a belief to be justified. Therefore, the conclusion of our argument that no moral belief can stop the regress need not entail skepticism.

31 The building metaphor is a bit oversimplified. While the first floor of a building may depend on the foundation for all of its structural support, a defender of the linear picture of justification need not claim that all of a belief's justification is derived from a foundational belief. The defender of the linear view only needs to claim that support from a foundational belief is necessary for an inferentially justified belief to be justified. For more discussion see Audi, Epistemology, pp. 210-11.

32 As mentioned above, $D$ only gives a necessary, not a sufficient, condition that a belief must meet in order to be justified in cases of disagreement. Thus, $D$ leaves open the possibility that disagreement defeats the justification of some or all of our moral beliefs even if coherentism is true. 


\section{Implications for Normative Ethics}

So far, our argument has remained in the realm of epistemology. However, as Descartes knew, epistemological questions are closely connected with methodological questions. ${ }^{33}$ Thus, we should not be surprised to see that work in moral epistemology may have implications for the methodology of normative ethics.

One of the things that normative ethicists do is argue from moral premises to moral conclusions. One goal of these arguments is to show readers that they are justified in believing the conclusions in question. However, an argument can only show that one is justified in believing a conclusion if she is justified in believing the premises of that argument. Thus, normative ethicists have reason to be concerned about the conditions under which we are epistemically justified in believing moral propositions.

It is common practice in normative ethics to appeal to intuitions about cases and use these intuitions to prove and disprove moral theories. This practice may be sound so long as we recognize that in order for us to be justified in believing the propositional content of these intuitions, we need to be able to show that these intuitions are supported by further reasons, either other intuitions or theoretical claims. This means that "biting the bullet" (i.e., simply rejecting the intuition) may be reasonable, especially if one can show that the intuition is not supported by further reasons..$^{34}$

Some philosophers oppose this practice because they are skeptical of case intuitions. For example, Peter Singer suggests the possibility that these intuitions "are likely to derive from discarded religious systems, from warped views of sex and bodily functions, or from customs necessary for the survival of the group in social and economic circumstances that lie in the distant past." "35 Rather than proceeding from case intuitions, Singer urges us to "search for undeniable fundamental axioms" and "build up a moral theory from them." 36

It is a consequence of this paper that even apparently fundamental ethical axioms require a further reason in order for us to be justified in believing them. These further reasons may come from other theoretical claims or even from case intuitions. ${ }^{37}$

One may wonder: if we cannot take either case intuitions or fundamen-

33 It is no coincidence that one of Descartes's most important works in epistemology was titled Discourse on Method (1637).

$34 \mathrm{My}$ point here is only about moral intuitions. However, I imagine something similar holds for epistemological intuitions. This means that for us to be justified in believing the propositional content of our epistemological intuitions, such as the ones I appealed to in section 1, they must be supported by further reasons, either other intuitions or theoretical claims.

35 Singer, "Sidgwick and Reflective Equilibrium," p. 47.

36 Ibid, p. 48

37 Theoretical claims are distinct because they have the aim of systematizing other propositions. Theoretical claims differ from intuitions in that they are typically arrived at by inference, usually abduction, while intuitions are not. 
tal ethical axioms as given, how should we proceed in ethics? I cannot give a complete answer to this question here but I believe the right answer is roughly that we must find case intuitions that are supported by other case intuitions as well as theoretical claims, and theoretical claims that are supported by case intuitions and other theoretical claims. We then must work back and forth to bring these theoretical claims and case intuitions into coherence with each other. In other words, I believe that the epistemological conclusions of this paper support the familiar Rawlsian view that moral philosophy must proceed by the method of reflective equilibrium. ${ }^{38}$ That the method of reflective equilibrium is the correct way for normative ethics to proceed is by now widely, though not universally, accepted. ${ }^{39}$ Thus, the methodological implications of our thesis are in line with standard philosophical practice. It is, however, an important result that standard philosophical practice is supported by considerations from epistemology.

Ryan Fanselow

University of Maryland

Department of Philosophy

rfanselo@umd.edu

\footnotetext{
${ }^{38}$ For discussion of the method of reflective equilibrium see John Rawls, A Theory of Justice (Cambridge, MA: Harvard University Press, 1971), $\iint 4$, 9, 87. The best exposition and defense of this method is Norman Daniels, "Wide Reflective Equilibrium and Theory Acceptance in Ethics," Journal of Philosophy 10 (1980): 83-103.

39 In addition to Singer, reflective equilibrium's critics include R. M. Hare, "Rawls' Theory of Justice," Philosophical Quarterly 23 (1973): 144-45, reprinted in Norman Daniels (ed.), Reading Rawls: Critical Studies of A Theory of Justice (New York: Free Press), 81-107; R. B. Brandt, A Theory of the Good and the Right (Oxford: Oxford University Press, 1979), ch. 1; David Copp, "Considered Moral Judgments and Moral Justification: Conservatism in Moral Theory," in David Copp and Michael Zimmerman (eds.), Morality, Reason, and Truth (Totowa, NJ: Rowman and Allanheld, 1984), pp. 141-68; Stefan Sencerz, "Moral Intuitions and Justification in Ethics," Philosophical Studies 50 (1986): 77-95; Robert Cummins, "Reflections on Reflective Equilibrium," in Michael DePaul and William Ramsey (eds.), Rethinking Intuition: The Psychology of Intuition and Its Role in Philosophical Inquiry (Latham, MD: Rowman \& Littlefield, 1998), pp. 113-28; and Allen Wood, Kantian Ethics (Cambridge: Cambridge University Press, 2008), ch. 3 .
} 